\title{
Key Audit Matters \\ Implementation on Public Sector Audit Report: Case Study of the Audit Board of Indonesia
}

\author{
Nathalya Tampubolon, Robert P. Tobing* \\ Faculty of Economic and Business, Universitas Indonesia, Jakarta, Indonesia \\ ${ }^{*}$ Corresponding author.Email: robert.tobing16@gmail.com
}

\begin{abstract}
The Audit Board of Indonesia's (BPK's) opinion is recognized as one of the assessments of the performance of state financial management performed by the Indonesian government, both from the central government and regional government. Government financial reports have different functions and characteristics from private financial reports. This affects the characteristics and functions of public sector audits. This study examined whether ISA 701 concerning Key Audit Matters (KAM) issued by the International Auditing and Assurance Standards Board (IAASB) is applicable to BPK opinion, as an effort to overcome the information gap between auditors and users of audit reports. This study did not aim to find the best solution to overcome the information gap between auditors and readers of audit reports. This study elaborated standards with common practice used by leading public accounting firms to implement these standards, and then adjusted to the nature and characteristics of audits applied to the public sector. This study also found that ISA 701 provides constraints, which then become opportunities, in its application. The conclusion of this study is that KAM is applicable to public sector audits, by making adjustments according to the nature and characteristics of the audited object.
\end{abstract}

Keywords: Audit, Audit Opinion, Financial Audit, Key Audit Matters, Public Sector Audit

\section{INTRODUCTION}

The Audit Board of Indonesia (Badan Pemeriksa Keuangan, BPK) is a supreme audit institution that examines the management and accountability of Indonesia's state finances (Indonesia, 2016). BPK perform three types of audits; financial audits, performance audits, and special purpose audits (Indonesia, 2016). The result of BPK's audits is reported in the audit report (Laporan Hasil Pemeriksaan, LHP) (Indonesia, 2016). In financial audits, BPK expresses an opinion which is included in the LHP (Indonesia, 2014). The format of opinion is regulated in the State Financial Audit Standards (Standar Pemeriksaan Keuangan Negara, SPKN) by BPK (2017). As a member of International Organization of Supreme Audit Institutions (INTOSAI), BPK is subject to International Standards of Supreme Audit Institutions (ISSAI).

In 2016, BPK faced 17 lawsuits over the LHP. During 2016-2017, seven LHPs were declared winners in kracht van gewijsde. Therefore, efforts are needed to reduce the emergence of lawsuits against BPK. One of the reasons for the emergence is the gap, in various dimensions, between BPK as a report maker and users of audit reports, as examined by Kristiningsih (2010) and Yuliati, Winarna, and Setiawan (2018). This gap is seen in terms of auditor responsibility and independence. Kristiningsih (2010) showed that there is a gap in expectationa in terms of auditor responsibilities between BPK auditors and all LHP users. There is also a gap in independency among BPK auditors, DPRD members and the community (Kristiningsih, 2010). However, there is no gap in independency between BPK auditors and inspectorate's investigators (Kristiningsih, 2010). Yuliati, Winarna, and Setiawan (2018) examined the gap between government auditors and users of audit reports in Yogyakarta. The results of the study show that there are gaps about the role and responsibility of the auditor in communicating the results of the audit and increasing the effectiveness of the audit (Yuliati, Winarna, and Setiawan, 2018). 
Boyd, Boyd and Boyd (2001) wrote articles about misunderstanding gap between users and makers of audit reports. One of the efforts that can be done to narrow the gaps on expectation of misunderstanding is by increasing public's understanding of audit, both its characteristics and limitations. In an effort to reduce the gap between the maker and user of the audit report, the International Auditing and Assurance Standards Board (IAASB) established International Standard on Auditing (ISA) 701, which was then adopted to ISSAI 1701, concerning Communication of Key Audit Matters (KAM) in Independent Audit Reports.

Banham (2018) examined the studies and writings published by the public accounting firm about the impact of KAM disclosures on investor reactions and audit quality in several countries. Banham (2018) concluded that the addition of KAM disclosures still needed to be questioned in an effort to reduce the gap between auditors and investors. Banham (2018) also wrote that some literature states that KAM disclosures can improve audit quality, including increasing the transparency of audit functions, increasing the sense of responsibility of engagement partners, enhancing the auditor's skepticism of professionalism on matters that are significant when conducting audits, as well as improving the quality of information for investors. However, some literature states that KAM disclosures have no impact on investors and audit quality (Banham, 2018).

This study examines whether KAM is applicable to BPK opinion, as an effort to overcome the information gap between auditors and readers of audit reports. This study did not aim to find the best solution to overcome the information gap between auditors and readers of audit reports. The purpose of this study was to answer the question of whether KAM is applicable to public sector audit report, what steps can be taken to establish KAM in the public sector audit report, and what information can be disclosed in the audit report with KAM in the public sector. The benefit of this study is to provide practical steps to implement KAM on public sector audit reports. This study was conducted in the public sector; this is different from previous research conducted in the private sector.

The results of the study indicate that KAM is applicable to public sector audits, by making adjustments according to the nature and characteristics of the object being audited. Public sector audits are intended to test government policies in the continuity of the state; therefore, the KAM disclosed are significant matters that influence the administration of state finances. The challenge in establishing and informing KAM in public sector audit reports is that ISA 701 is not detailed enough on regulating the steps and the components. However, this challenge raises an opportunity, which is flexibility. ISA 701 is more flexible to be applied in various sectors, including the public sector. The solution to the study is to improve understanding of audit characteristics and audit objects so that they can compile information needed to present KAM elements in public sector audit opinions. Hopefully, this study can provide insight for examiners who conduct financial audits in the public sector, as well as for academics and professionals in drafting regulations or standards for public sector audit reporting.

In the next section, a literature review is presented, followed by an overview of the objects of research, analysis and discussion, and conclusions and research suggestions.

\section{LITERATURE REVIEW}

\subsection{Agency Theory}

Agency theory regards the existence of a contractual relationship between the assignor called the "principal" and the executor of the task called "agent" (Eisenhardt, 2018). The study found that agency problems arise when: the principal and agent have different objectives, and the principal cannot determine whether the agent has acted according to the agreement or not (Eisenhardt, 2018). If the agent carries out moral hazard, namely an action that has a different purpose, or makes a conflicting decision, the principal can: improve the information system, or list the desired results in the contract (outcome-based contract) (Eisenhardt, 2018).

Agency theory can be implemented into BPK audit, because there is a contract based on Article 23E of the 1945 Constitution, which appointed BPK as an agent, and the people of Indonesia (represented by the DPR/DPRD) and other stakeholders as principals. The problem that arises between BPK as agent and BPK's stakeholder as principal is the gap due to the differences in perceptions in various dimensions between BPK and BPK's stakeholders. Boyd, Boyd and Boyd (2001) stated that the expectation gap is the perception gaps that occur between auditors and the public of the audit report, namely:

- the gap between people's expectations of the achievement of auditor, and what can rationally be expected to be achieved by the auditor (Boyd, Boyd \& Boyd, 2001);

- $\quad$ the gap between what the expected auditors can accomplish and what the auditor can really achieve (Boyd, Boyd \& Boyd, 2001).

The expectation gap can be reduced by increasing public understanding of the nature and limitations of audits (Boyd, Boyd \& Boyd, 2001). 


\subsection{Key Audit Matters}

"Key Audit Matters-those matters that, in the auditor's professional judgment, were of most significance in the audit of the financial statement of the current period" (IAASB, 2015).

KAM is stated in ISA 701 concerning KAM communication in an independent auditor's report fully adopted by INTOSAI in ISSAI 1701. In addition to ISSAI 1701, INTOSAI issued Practice Notes, namely supplementary guidance for implementing ISA 701 in the public sector. A public sector auditor may be required to communicate KAM such as the importance of government policies to the economy and the significant impact of a government's policies and decisions on the citizens that it serves (INTOSAI, 2015).

The purposes of KAM communication in audit reports, among others, are to improve communication and transparency of audits, provide additional info and help report users to understand important assessments/assumptions in financial report (IAASB, 2015). However, KAM is not intended to be a substitute for disclosures in the financial statements; for the auditor expressing a modified opinion; for reporting events or conditions that may cast significant doubt on an entity's ability to continue as a going concern; or for a separate opinion on individual matters (IAASB, 2015).

The main steps for communicating KAM in audit reports in accordance with ISA 701 is presented in Fig. 1. Matters considered as the significant are (IAASB, 2015): areas of higher assessed risk of material misstatement, areas that involve significant management judgment, and significant events or transactions that occurred during the period of financial statements (IAASB, 2015). The auditor must assess the most significant matters in the audit of the current period; these are the KAM (IAASB, 2015).

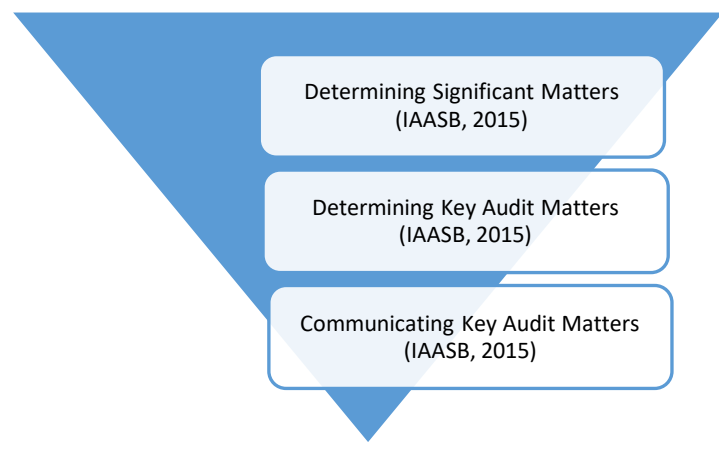

Figure 1. Determining and Communicating KAM in Audit Report (ISA 701, 2015)
Things that need to be communicated:

- a statement that KAM are the most significant in concluding audit result (opinion) (IAASB, 2015);

- a statement that KAM is inseparable matters in current period of financial statement (IAASB, 2015);

- an explanation in a separate section for each KAM describing the reason the matter is significant and how auditors respond on the matter (IAASB, 2015).

The auditor must describe each KAM, unless: law or regulation precludes public disclosure about the matter, or the auditor determines that the matter should not be communicated in the auditor's report (IAASB, 2015). ISA 701 regulates KAM communication in audit opinion other than those that are unqualified:

- Modified unqualified: KAM is not intended to replace explanatory paragraphs (IAASB, 2015);

- Qualified: KAM is not communicated for significant matters other than excluded matters (IAASB, 2015);

- Adverse: KAM is communicated for significant matters other than matters that make the presentation of financial statements unfair, plus a statement that it does not have a greater influence than other matters that cause financial statements to be unnatural (IAASB, 2015);

- Disclaimer: KAM is not communicated in auditor's opinion (IAASB, 2015).

\section{RESEARCH METHODOLOGY}

This research was a qualitative case study because this study used qualitative data and qualitative analysis and applied it to the research object. Data processing used induction analysis, performed by looking for patterns from existing data and grouping them to be analyzed according to the framework specified in ISA 701 as the main guideline, elaborated by examining the methods used in leading public accounting firms and then adjusted according to the characteristics of the public sector. The data used are secondary data, namely reports issued by BPK and written information issued by accounting firms. The common practice used in research is the method of applying KAM used by Deloitte and KPMG. Deloitte and KPMG methods were chosen because these firms have implemented ISA 701 in their audit reports. In addition, these firms are the world's leading international public accounting firms. These methods were then compared, and adjusted to the characteristics of the audit in BPK. The results of the analyses were formulated into practical steps ISA 701 to BPK audit report. 


\section{ANALYSIS}

LHP BPK has different forms and characteristics from audit reports in general. In general, audit opinions are included in the sheet in the Audited Report. LHP BPK is separately presented with state's audited financial statements. In contrast, the LHP BPK includes state's audited financial statements. The LHP BPK consists of three parts: Part 1 includes opinion sheets and audited financial statements; Part 2 is the report on the results of an audit of internal control; and Part 3 is the report on audit results of compliance. Part 2 contains the findings of internal control weaknesses that can affect the fairness of the financial reporting being examined. Part 3 contains the findings of weaknesses in the implementation of management of state finances that violate applicable laws and regulations.

Parts 2 and 3 of BPK LHP are "things that need to be communicated with those who are charged with governance/TCWG." With the existence of KAM, it is expected to "bridge" Part 1 with Parts 2 and 3 of the audit report. The following paragraph presents the practical steps to determine and communicate KAM to the LHP BPK based on ISA 701, adjusted to the characteristics of the public sector, and taking into account the applied methods of Deloitte and KPMG.

\subsection{Determining Significant Matters}

ISA 701 states that auditors must find a significant matter that requires more attention in conducting audits, i.e., things that need to be communicated with management (TCWG) (IAASB, 2015). Significant matters can be found, e.g., in areas that have a high risk of misstatement (IAASB, 2015); in areas that require a significant assessment of the auditor or management (IAASB, 2015); or where there is an impact of a significant event or transaction (IAASB, 2015).

The method used by Deloitte in identifying significant matters is almost the same as that set out in ISA 701, adding special attention to other matters that require significant attention from auditors (Deloitte AG, 2017), such as the application of new technology information systems (Deloitte AG, 2017). The method used by Deloitte can be used in public sector audits, because technology information systems also have an impact on the fairness of state financial management.

The method used by KPMG to identify significant matters considers areas with significant complexity and management judgment, which affect audit strategies, allocation of resources, and improvement of overall audit efforts; significant events/transactions; important accounting estimates; and matters that become obstacles for the auditor to obtain adequate audit evidence in giving opinion (KPMG Phoomchai Audit Ltd, 2017).
The method used by KPMG is more practical, and it is more convenient to implement in BPK audit.

As significant matters for public sector audits, in addition to matters specified in the standard, auditors must also consider new regulations/policies related to management and accountability of state finances; nonfinancial audit results in the current year; opinions and findings of the years before; and follow up on previous findings. In each examination of the financial statements, BPK has paid attention to these matters, and has stated significant deviations in Parts 2 and 3 of the LHP BPK. Therefore, BPK's findings are in accordance with the significant matter concept regulated in ISA 701.

\subsection{Determining Key Audit Matters}

IAASB (2015) stated that, among the important matters that require the attention of the auditor (Paragraph 9) that have been predetermined, the auditor must determine the most significant matters in the financial statement audit in the current period, i.e., KAM. IAASB (2015) did not state in detail the method for sorting out KAM from significant matters. This creates an obstacle in implementing ISA 701 in the audit. On the other hand, IAASB (2015) provided an opportunity for auditors to use professional judgment in assessing the most significant things in accordance with the characteristics of the financial statements being examined.

The method used by Deloitte to determine KAM is giving attention to the significance between the auditor, management, and the audit committee; the effect on understanding the financial statements as a whole; materiality; misstatement and its nature; complexity of accounting policies; the nature and extent of the audit effort related to this matter; and severe control system weaknesses and its relation to other things (Deloitte AG, 2017). The method used by Deloitte is similar to the steps previously taken in determining significant matters and is less measurable. However, this method is still applicable to assist auditors in determining KAM in the public sector.

KPMG did not state certain methods for determining KAM, but, in one of its audit reports with KAM (KPMG Phoomchai Audit Ltd, 2017), KPMG used "Dynamic Audit Planning Tools" to sort out KAM from "significant matters" (KPMG, 2016). KPMG Dynamic Audit Planning Tools measure the likelihood of material misstatement and the potential impact in financial statements generated by each significant matter (KPMG, 2016). Things that have a high potential impact are grouped into KAM. The method used by KPMG is more practical to apply to BPK audit, although it cannot be fully adopted. 
Adopting the KPMG method in the public sector, the likelihood of a finding can be determined by looking at the occurrence of the findings in previous years or on how many work units are included in the findings. While the potential impact of the findings can be seen from the value of the findings, the impacts of the findings on the achievement of the expected output or other output units are used as performance measurement tools. Each work unit in the public sector has a performance measurement unit set out in the State/Regional Expenditure Budget (APBN/D) document. This method is more measurable and can be used as a final step to determine KAM in public sector audits.

\subsection{Communicating Key Audit Matters}

The adequacy of KAM disclosures in opinion is determined by a professional judgment auditor. However, IAASB (2015) stated that KAM are communicated to a separate section of the opinion entitled "Key Audit Matters," which includes related disclosures (if any) and mentions: why they are considered to be one of the most significant in the audit so that they are defined as KAM, and how they were treated in the audit.

In the KAM section, the auditor must state the language of instruction that: KAM are things which, in the auditor's professional judgment, are the most significant in the financial statement audit (on the current period); and these matters are determined in the context of the overall financial statement audit, in the determination of the relevant auditor opinion, and the auditor does not provide a separate opinion on these matters (IAASB, 2015). KAM are not communicated in the audit report, if they are prohibited by regulations, and if their being published can harm the public interest (IAASB, 2015). In addition to the reasons stipulated as KAM and KAM's risk of financial reporting, IAASB (2015) did not provide more detailed information regarding the adequacy of disclosures for each KAM. The adequacy of more detailed disclosures and arrangements is a concern of the public accounting for proposals ISA 701 (Cordos \& Fulop, 2015). In addition to being an obstacle in its implementation, ISA 701 provides an opportunity for auditors to use their professional skills in determining what needs to be disclosed and the adequacy of KAM disclosures, according to the characteristics of each auditee.

The method used by Deloitte in KAM disclosure is to include references to notes to financial statements (if any); explanation of why this was considered KAM; and an explanation of how this was handled in the audit (Deloitte AG, 2017). This method is the same as that set out in IAASB (2015).
The method used by KPMG in KAM disclosure is to include audit responses; a brief explanation of the audit procedures performed; indication of the results of the audit procedure; and core things observed related to KAM (KPMG Phoomchai Audit Ltd, 2017). The KPMG method is more detailed, but less practical to implement in BPK audit. In addition to the results of audit procedures, conclusions from the audits related to KAM are needed, so that KAM disclosures do not become ambiguous and thus increase the gap between auditors and report users.

Adopting ISA 701 into BPK audit, considering the Deloitte and KPMG methods, there are four elements proposed for KAM disclosures in the public sector:

- Risks, namely an explanation of why this, in the auditor's judgment, is the most significant thing in the audit (KAM).

- Responses, which is an explanation of how the audit treatment of KAM.

- $\quad$ Findings, namely disclosure of findings related to KAM, as well as follow-up actions that have been made regarding the findings. The findings and follow up indicate that there is indeed a risk related to this, and whether it has been handled properly.

- Conclusion, namely the conclusion of the results of the examination of the impact of KAM on the fairness of overall financial reporting. Conclusions require professional judgment from the auditor, and cannot be concluded by the reader of the audit report alone, without adequate knowledge or competence.

\section{CONCLUSIONS}

ISA 701 concerning AM is applicable in public sector audit reports, in this case, Reports on Audit Results of Financial Reports issued by BPK. The application of ISA 701 is constrained by the lack of detail in regulated steps and limits. However, these constraints provide an opportunity for auditors to use their professional skills, by making adjustments according to the characteristics of the object being audited, so that the objectives of disclosing KAM can be achieved.

KAM disclosures are not an absolute solution to bridging the communication gap between auditors as makers of audit reports and readers of audit reports, but it is a reasonable effort to reduce the gap.

\section{REFERENCES}

[1] Banham, R. (17 October 2018). 'Critical audit matters coming into Focus'. Journal of Accountancy, 2018 [Web]. Association of International Certified Professional Accountants. 
[2] Boyd, D. T., Boyd, S. C. and Boyd, W. L. (8 May 2018). 'The audit report: A misunderstanding gap Between users and preparers'. The National Public Accountant, Dec 2000/Jan 2001 [Web]. ProQuest, 45, 1056.

[3] BPK 2017 The state financial audit standards.

[4] Cordos, G. F. and Fulop, M. T. (2015). 'Understanding audit reporting changes: introduction of key audit matters'. Journal of Accounting and Management Information Systems, 14(1), pp. 128-152.

[5] Deloitte, A. G. (14 April 2017). 'The new auditor's report', 2016 [Web].

[6] Eisenhardt, K. M. (1989). “"Agency Theory: An Assessmenet and Review"'. The Academy of Management Review [Web], 14(1), pp. 57-74.

[7] IAASB 2015 The international Standard on auditing (ISA) 701.

[8] Indonesia, (2016). 'Audit Board of Indonesia Law', Art, pp. 1-6.
[9] Indonesia, (2004). 'Examination of state financial management and responsibilities law', Art, 16, par. 1.

[10] INTOSAI (2015). The international standards of supreme audit institutions (ISSAI) 1701.

[11] KPMG (2016). Audit Report of Rolls-Royce Holding Plc. For the Year ended December 31, 2015.

[12] Kristiningsih, R. 2010 The expectation gap analysis on auditing financial statements of local governments in Central Kalimantan Province. Gajah Mada University.

[13] 'Beyond auditor's report' [Web]. KPMG International, 2016.

[14] Yuliati, R., Winarna, J. and Setiawan, D. (20 Dec. 2018). 'Expectation gap between users of government financial reports and government auditors', 2007 [Web]. 